\title{
Fair Value Accounting and Measurement through FASB's Developments
}

\author{
Carmen Giorgiana BONACI ${ }^{*}-$ Jiři STROUHAL ${ }^{* *}$ \\ Dumitru MATIS ${ }^{* * *}$
}

\section{Fair Value: Standard of Value in Financial Reporting}

Despite the fact that, in order to obtain a true image using financial reports, the use of both quantitative and qualitative information is necessary, we must also consider the concept of value, a concept that is of crucial importance, due to its obvious, yet complex meanings. In addition, the evaluation (quantification) of qualitative information can be a theme of discussion on its own. We all agree that "beauty lies in the eyes of the beholder", therefore we must ask ourselves: Isn't this idea also true in the case of value? Alternatively, in other words, can value depend on the subjective opinion of the assessor? (Fishman et al., 2007). We agree on the hypothesis that value cannot be acknowledged universally until it is defined. Trade literature considers the different definitions of value (together with various auxiliary information) as being standards by which it can be judged (i.e. standards of value).

\# The authors' research activities for this paper have been funded by the research projects CNCSIS 2571/2009 Developing a conceptual integrated and self sustainable model regarding financial reporting within Romanian private sector entities, CNMP 92-085/2008 Developing a functional model for optimizing the national strategy regarding financial reporting within Romanian private sector entities and GA402/08/P024 Analysis of Measurement and Valuation of Financial Securities by Listed and Non-listed Companies in CR registered at Czech Science Foundation.

Carmen G. Bonaci, Ph.D. - Lecturer; Babes-Bolyai University Cluj Napoca, FSEGA, Department of Accounting, Theodor Mihali 58-60, 400591 Cluj Napoca, Romania, <carmen.bonaci@econ.ubbcluj.ro>.

** Ing. Jiří Strouhal, Ph.D. - Senior Lecturer; University of Economics Prague, Department of Financial Accounting and Auditing, W. Churchill Square 4, 13067 Prague 3, Czech Republic; <strouhal@vse.cz>.

**** Prof. univ. dr. Dumitru Matis - Professor; Babes-Bolyai University Cluj Napoca, FSEGA, Department of Accounting, Theodor Mihali 58-60, 400591 Cluj Napoca, Romania; <dumitru.matis@econ.ubbcluj.ro>. 
From a very pragmatic point of view, the evaluation process can be seen as being nothing more than the search for an answer to a very important question: "What is the value of...?" (Fishman et al., 2007). Before parting in our quest for the appropriate answer, a definition of value must be given. We consider that this definition should start with the identification of the right value standard, i.e. the necessary type of value. Every standard of value contains a series of assumptions that represent the essence of the type of value used in a certain conjuncture. Furthermore, once that standard has been chosen, there is no guarantee that it will benefit the unanimous approval of its assumptions.

The most widely used value standards are "fair market value" and "fair value". A linguistic approach to the two terms indicates that "fair value" is a more comprehensive notion, because it refers to a value that is "right and correct". The "right and correct" concept is a more permissive one, the best way to illustrate it is by giving an example: the right value of an asset can be represented by its value on the market, by its intrinsic value, by its exchange value, or, in some situations, by the liquidation value of that asset. The concept of fair market value is a more restrictive one, due to the presence of the term "market". This trait can make one ask himself weather the term "market" is linked to the adjective "fair" (like in "fair market") or the noun "value" (like in market value). We are obliged however to determine the value we would receive on the market - during a real or a hypothetical transaction - in exchange for an asset. The "fair market value" represents the base of all judgments of value, while "fair value" is defined in terms of financial reports.

References to standards of value appear from the beginning of the 19th century, without the term being defined. It was in the second half of the 19th century when the development of the railways allowed the expansion of trade, thus favoring corporations and generating the necessity of evaluation solutions (algorithm) for properties (which had to be taxed), for settling disputes among shareholders etc. At the beginning of the 20th century, law courts, states and other regulation offices begun to be confronted with various litigations, which evolved business evaluations. Terms like "willing buyer", "willing seller" or "knowable", started being mandatory in the process of determining fair market value in the 1920s. Things started changing even more in the last half of the 20th century, when the most valuable assets of an economic entity begun to be intangible, rather than tangible. Therefore, the evaluation process had to 
evolve too, in order to keep up with the times. A more complex evaluation method was badly needed.

After this short plea dedicated to the term "value", we will concentrate on "fair value" as standard of value for financial reporting. We try to depict an overview of what "fair value" means, insisting only on the situations that regard financial instruments.

\section{Methodological Approach}

A good understanding of fair value, in its acceptance as a standard of value for financial reporting, needs a short excursion in the historical evolution of the term and the regulations, which endorse it. We chose to insist on the American accounting referential considering current circumstances involving the financial crisis that started in the US, many blaming fair value accounting.

The analysis of American accounting standards, which regard the concept of fair value, did not allow us to initiate a deductive approach, which could have been used to start from a general level, than continuing to a more particular one, i.e. the specific field of financial instruments. This is a consequence of the fact that it was the field of financial instruments, which brought into discussion the necessity of using fair value as attribute of the evaluation process, future evolutions demonstrating the need for a standard with widened applicability. Therefore, the sequence of events dictated by the historical reality guided us to an inductive approach.

Fair value has been a term used in the accounting literature for a considerable period of time, but without ever being defined. Thus, a proper analysis of the evolution of this term is needed, a useful tool in this approach being the American accounting referential. The analysis of accounting standards foresights concerning fair value evaluation, and the influence these notions have on the information provided by the financial situations, are correlated with aspects of today's financial crisis.

\section{FASB Developments on Fair Value}

The "fair value" term appeared for the first time in 1953, in the 43rd number of Accounting Research Bulletin, which bearded the title 
Restatement and Revision of Accounting Research Bulletins. Afterwards, the term appeared in Accounting Principles Board Opinions - APB (Accounting for Non-monetary Transactions - 1973), and in the FASB 15 - Statement of Financial Accounting Standards (Accounting by Debtors and Creditors for Troubled Debt Restructurings - 1977). An interesting thing is that before the project that led to the elaboration in 2004 of the fair value evaluation exposure, FASB resorted to the definition and use of fair value standard mainly about the reports that concern various instruments. Therefore, in 1986, FASB added to its agenda a project that focused on financial reporting, which made possible the introduction of SFAS 107 - Disclosures about Fair Value for Financial Instruments in 1991, and, in 1998 of SFAS 133 - Accounting for Derivative Instruments and Hedging Activities. Through these two SFAS, the FASB set a long-term objective, that is, the evaluation of all financial instruments at their fair value.

During the Annual Conference on Current Securities and Exchange Commission Developments, which took place in 2001, a member of the managerial team held a speech about the fair value, a speech that was aimed at financial instruments, but did not disregard the wide impact it (the fair value) had on all the elements that need fair evaluation for financial reports:

\footnotetext{
Regulatory bodies need to offer more detailed indications concerning the way of accounting, evaluation and auditing. The representatives of the accountant profession (occupation) must collaborate with each other, and with other parties involved, for example the users of the financial information, audit experts etc. The professionals in charge with the elaboration of financial situations (reports), the auditors and the users of this kind of information have to be better prepared in the field of fair (just) value accounting (Fishman et al., 2007).
}

The imperative "have to" has an important significance, because it underlines the challenge to which regulations organisms have responded more and more actively in the last few years, developing the issue of fair value for financial reporting. It is important to mention that in 2000, FASB has emitted Concepts Statement No. 7, Using Cash Information and Present Value in Accounting Measurements. This Statement can be considered a result of a project, which was included in the FASB since 1998, with the declared goal of analyzing crucial aspects regarding current value in accountant evaluations. 
In 2003, the FASB created a Valuation Resource Group (VRG) whose objective was to provide support to the Council in matters of fair value evaluation (FASB, 2004). This group was made up from accountant experts, auditors and expert evaluators. Around this time, the ASB (Auditing Standards Board) emitted SAS 101 - Statement of Auditing Standards - Auditing Fair Value Measurements and Disclosures. The next step consisted in the elaboration in 2004, by FASB, of the exposure project (ED), regarding the evaluation of fair value, this particular goal being a more complex one: the development of a conceptual framework that would clarify this matter in such a way, that it could be applied for all assets and entity liabilities (FASB 2004). After the presentation, debates and deliberations, a first sketch of this framework was finally introduced in October 2005, followed by a second one in March 2006. Finally, in the autumn of 2006, SFAS 157 - Fair Value Measurements was officially introduced.

The reality is that theory and practice of fair value, in the field of financial reporting, has developed gradually, throughout time. (FASB, 2004)

As FASB declares, "the objective of fair evaluation is to estimate an exchange price for an asset or a liability, which are evaluated in an absence of a transaction that would involve them". (FASB, 2004) In a more precise way, this objective assumes that fair value should be defined in such a way that the exchange price of the asset or the liability should fully reflect the real value of that asset/liability. In other words, the price at which an asset can be exchanged between two entities does not depend on the entities involved in the exchange, the asset's price residing in its value-in-use for every entity. For example, the value of a swap instrument for a bank reflects the price at which that bank can buy or sell that derivative, that value not being dependent of the assets or liabilities in the bank's balance sheet. In a situation like this, Barth and Landsman (1995) consider that an assumption like this is a risky one, especially if the bank's assets or liabilities are not traded.

In the US, FASB has emitted a series of standards that impose the presentation or acknowledgement of fair value. Among the most significant ones, in terms of relevance for financial institutions, are those standards that refer directly to financial instruments. Two important standards that concern the way of presentation are SFAS 107 Disclosures about Fair Value for Financial Instruments and SFAS 119 Disclosure about Derivative Financial Instruments and Fair Value of 
Financial Instruments. SFAS 107 demands presentation of fair value for all acknowledged assets and liabilities, being the first standard that offers investors estimations concerning balance sheet elements, securities, loans, deposits, and long-term debts. This was also the first standard that offered a definition for fair value, reflecting the objective of FASB to use market prices when it was possible, and the first standard which requested presentations regarding assessments made about the fair value of financial instruments, including futures contracts, forwards, swaps, and options. Information presentations about estimations of earnings and losses of financial instruments owned for trade are also demanded.

Amongst the most important standards emitted by FASB, standards which target the acknowledgement (accreditation) of fair value are: SFAS 115 - Accounting for Certain Investments in Debt and Equity Securities, SFAS - 123 (revised) Share-based Payments, and SFAS 133 Accounting for Derivative Instruments and Hedging Activities. SFAS 115 requests the recognition of fair value of investments in securities representing shareholders' equities or financial liabilities, classified as trading securities or available for sale. Changes in fair value of trading securities are reflected in current earnings, in comparison with the ones connected to available for sale category, when gains and losses on those securities bypass income and are reported in equity as an adjustment to other comprehensive income. Held to maturity, securities are not markedto-market; rather, unless there is other-than-temporary impairment in value of those securities, they are reflected in the financial statements at amortized cost.

SFAS 123 (revised) eliminates the possibility of choosing the fair value and the intrinsic one in cost evaluation (as it stated in 1995 Accounting for Stock-based Compensation), by imposing the usage of fair value at the time the adjustment and reported earnings are affected.

SFAS 133 demands that all independent derivatives must be acknowledged at their fair value. However, this standard keeps elements from the accountancy model for hedge operations. Especially, the changes in fair value of those derivatives used in risk-covering operations regarding fair value (for example the low interest rate risk and the risk of the prices of goods) are reflected in the income statement, the same being true in the case of changes in the fair value of the hedge element representation in the balance sheet, or in the case of entity engagements (for example forward contracts). If the so-called fair value hedge is 
perfect, the effect on the income statement of the hedge relation is zero. Contrary, the changes in the fair value of those derivatives that have cash hedging as their goal (for example the volatility of cash flows induced by the interest rate risk or the evolution of goods prices), are represented as a distinct component of shareholders' equity, due to the fact that there is no compensation or change that can be acknowledged in terms of fair value of a hedge element in the balance sheet.

\begin{abstract}
FASB has emitted a series of other standards, which comprised elements that specifically discussed information or evaluations of fair value. For example, SFAS 87 - Employers' Accounting for Pensions, which demanded presentations in form of notes that would reflect the fair value of assets represented by pension plans, and the obligations which concerned pensions which have been associated to benefit plans that have already been finalized. However, the standard only requested the acknowledgement in the balance sheet of the net values of the sums of assets, shareholders' equity and liabilities. The SEC report of 2005 recommends that representation in financial reports of assets and liabilities concerning pensions should be made at their fair value. Landsman (1986) and Barth (1991) demonstrate that the shareholders' equities price reflects the fair value of pension assets and liabilities.
\end{abstract}

Having in mind the elements concerning fair value, which have been presented above, and the context in which the American accounting regulations from the beginning of the 21 st century are included, we can describe two essential motivations that determined the FASB to draw up a standard that would represent a procedural guide, which would be used for estimating fair value, and which could be applied to a wide range of financial and non-financial assets (Botosan et al. 2005). On one side, the set of accounting standards available around 2004 did not include a unique source of general guidance, valid in the attempt of defining and estimating fair value. The guidance that concerned fair value could be found mainly in a series of intersected and "patched" accounting standards, which referred to financial instruments. On the other side, the exiting accounting standards showed an increasing level of the acceptance of fair value as attribute of evaluation (in comparison with the depreciation cost). Assuming that there is a high probability that future standards will include evaluation at fair value, the definition of this concept (fair value) as attribute of evaluation - accompanied by procedural guidance at the highest level, and concerning a consistent estimation of the concept - became a priority in the goal of the efficient application of already existing or new standards. 
The goal of this new standard was to assist the users of information provided through financial reports, so that they could evaluate more appropriately the relevance and credibility of the estimations of fair value. The financial reports should also contain information about the data and models used to provide fair value estimations.

The standard created by FASB in the autumn of 2006, SFAS 157 Fair Value Measurement seems, on one side, to judder the foundation of historic cost based evaluation, but, on the other side, appears harmless because it does not impose the use of fair value on a wide scale (Miller and Bhanson, 2007). In fact, the truth lies, as usual, somewhere in the middle, in the way that the standard acts both ways.

Indeed, the new standard does not impose the use of fair value in situations other than the ones already mentioned by previous standards. However, SFAS 157 modifies the 'status quo' in three essential ways. We refer here to the fact that the level concerning practical aspects is being raised, a new series of factors that must be considered is emerging. These factors must be taken in consideration when those fair values already mentioned in existing GAAPs are evaluated, so that the evaluation process can disclose information that is more important. Another effect was that the introduction of SFAS 157 cleared the way for SFAS 159 The Fair Value Option for Financial Assets and Financial Liabilities. SFAS 159 created the possibility for fair value to be introduced and used in new ways. Another merit of this standard was that it prepared the field of financial reporting for the new Conceptual Framework developed by FASB. We rely on these affirmations and on the preliminary aspects contained in the Objective of Financial Reporting and Qualitative Characteristics of Decision - Useful Financial Reporting Information, introduced in 2006 by the same FASB. These stated that the fair value will be ultimately preferred as an evaluation attribute in financial reports (FASB, 2006). In this context, the introduction of SFAS 157, was meant to clarify and put things in order, is fully justified.

It is thus clear that the objective of the issuing of SFAS 157 is to bring uniformity and consistency to the professional literature, and to accounting practice. One of its great contributions resides in the fact that it offered a real catalog of situations in which fair value is used, and a standard annex presenting more than 60 cases in which fair value is valued and reported. 
The standard defines fair value as being "the price that would be received to sell an asset or paid to transfer a liability in an orderly transaction between market participants at the measurement date" (SFAS 157.5). With a bit of concentration, we can observe that this definition is in fact, the solution offered by the Council, skilful and conciliatory, delivered in a subtle way, so that the long controversy about the evaluation of fair value is ended.

There are voices that disapprove the solution chosen by FASB in defining the fair value starting from exit values, considering that this affects the relevance of the offered information, and not reflecting the value of the assets from the point of view of their role within the entity's specific operations. In other words, fair values determined in this ways will not offer the investors correct information regarding the future cash flows that will be generated by these assets within the entity, fact that represents the fair value from the point of view of the stockholders. Implicitly, it can be appreciated that these exit values fail to fulfill the financial situation's informational objective or even the stewardship function because it would not evaluate in a corresponding way the managers' capacity to create value for stockholders (Ronen, 2008). From this point of view, the relevance of these values is just partial, offering useful information in appreciating certain aspects of the risk the entity is exposed to.

Drawing out conclusions from this standard, recognizing its merit to bring a series of other standards in the 21st century, and a plus of rigueur in what regards the estimation of the fair value. Any appreciation at the address of this standard, though, would be incomplete without referring to its role in offering a true launching ramp towards new growth initiatives of the utilization of the financial situations through the intermediation of some future standards regarding fair value, but also for a new conceptual frame that surely will need evaluation of the fair value in several situations, financial ones, or presentations of extra information.

This was realized already at only 6 months from the appearance of SFAS 157, through the emission made by FSAB in February 2007 of SFAS 159 The Fair Value Option for Financial Assets and Financial Liabilities, whose elaboration, adoption and implementation surely would have been harder to realize if the basis would not have been put through its predecessor. The good part of SFAS 159 regards those innovative managers that will profit on the permissively of the standard like an 
occasion to increase voluntarily the quantity of information useful on the capital markets, through the intermediation of the offered financial information. We are not to forget though the possibility of exploration of its flexibility in offering a false image over some of the financial assets and debts of the entity, as a negative effect of the managers' innovative capacities, stimulated through the standard. The theory offers us though an answer when facing this danger, considering these efforts negatively oriented, with a great lack of ethics, and un-useful, due to the fact that, earlier or later, capital markets will impose the well deserved punishment through the diminution of the quoted prices and the increase in capital costs. It is not to neglect the necessity of developing some mechanisms of corporative governance meant to encourage honest financial reports and objective ones (Ronen, 2008).

SFAS 157 had the role to establish a conceptual frame for fair value evaluation, applicable to American standards, having information regarding the process afferent to the evaluation. In other words, this new standard does not impose new fair value evaluations, but only clarifies, at a more general level, the modality of applicability, in these situations that permit and solicits the evaluation of fair value through the aid of accounting regulation. With all these, for some entities, its' implementation imposes changes in current accounting practices.

SFAS 159 allows the entities to evaluate certain financial assets and debts at a fair value; this operation does not impose the entities to respect the relative complex requirements afferent to risk covering accounting (hedge), foreseen within SFAS 133. The goal of this new standard that introduces the fair value option, is in fact, to allow the entities to concentrate upon the choosing and respecting the advices that regard the implementation of the fair value, rather than upon the creation and the forming of the documentation necessary for the transactions to be according to the SFAS 133 spirit, and to the hedge's advices.

Regarding generally upon this standard there are some aspects extremely interesting to retain. On the other hand is the fact that its applicability is optional and even more, SFAS 159 permits the consideration of the applicability from case to case, for each instrument. On the other side the standard has raised serious disapprovals between two from the seven members of the Council for Financial Accounting Standards of USA, one of them appreciating that through the aid of such a standard "the complexity and the costs are transferred towards the users, 
these having the duty to invest more effort and to support more costs, in order to be able to compare financial situation made through the utilization of the option towards fair value with those financial statements made through the utilization of other evaluation basis" (Wolosky, 2007), despite the fact that the lines in SFAS 159 solicits all the possible information in order to help the users put in such situations.

Emitted at only 5 months after SFAS 157, SFAS 159 encourages the reporting entities to choose the fair value option in evaluating the eligible financial assets and debts, while once chosen this option becomes irrevocable. Some voices in specialty literature seam suspicious regarding the chosen moment for the emission of this standard, considering that it could have been a reaction regarding the future crisis that will manifest. Many entities hoped even in a postponement from FASB's part for the implementation term of SFAS $157^{1}$. The sub-prime market issue creates damages within diverse capital markets around the world. Many entities were obliged to reduce the value of the assets reflected within the financial statements, because not only the burst of the housing bubble, but now also because of the implementation of SFAS 157. Through the aid of the optional criteria highlighted within the SFAS 159 standard regarding certain assets, some entities could even find modalities to loosen up this descending spiral, even though for a short period of time (Beeler, Evans, Turner, 2009).

The reasoning that favors the adoption of the fair value include the will of a better administration of the balance sheet, the necessity of some alternatives at SFAS 133 or the possibility of a better reaction at the changes appeared at the level of the interest rates (Ratcliffe, 2007). In adopting the option of fair value introduced through the aid of SFAS 159 is necessary to respect what is stated in SFAS 157, its' predecessor. As we have previously mentioned, the fair value option is implemented through the consideration of each single element, while excluding other elements from the same category or from a similar category of instruments. Once chosen the fair value option, the decision is irrevocable. In the case of the already existing financial assets and debts within the entity, this can also implement the fair value option once with the choice of using the recommendations within SFAS 159. Even more,

1 SFAS 157 emitted in September 2006, as well as SFAS 159 emitted in February 2007 imposed an effective application from 15 November 2007, the date of the new financial exercise, permitting the early application from the beginning of 2007. 
the entities can choose to apply the fair value option, after the initial adoption, at the date at which the eligible elements are recognized.

As an example, after the initial implementation of the standard SFAS 159, an entity that assumes an eligible commitment can opt for a fair value accountability of this commitment.

The next chart synthesizes the elements to which we can apply the fair value option, as well as those that are not in the applicability area of SFAS 159:

Tab. 1: Applicability of SFAS 159

\begin{tabular}{|l|l|}
\hline Eligible Items under SFAS 159 & Non-eligible Items under SFAS 159 \\
\hline $\begin{array}{l}\text { Loans, receivables and } \\
\text { payables }\end{array}$ & $\begin{array}{l}\text { Investments in subsidiaries that are } \\
\text { required to be consolidated }\end{array}$ \\
\hline $\begin{array}{l}\text { Investments in equity } \\
\text { securities, including } \\
\text { investments accounted for } \\
\text { using the equity method }\end{array}$ & $\begin{array}{l}\text { Interests in variable-interest entities } \\
\text { that are required to be consolidated }\end{array}$ \\
\hline $\begin{array}{l}\text { Rights and obligations under } \\
\text { insurance contracts }\end{array}$ & $\begin{array}{l}\text { Assets and obligations associated } \\
\text { with pension and other post- } \\
\text { retirement benefit plans }\end{array}$ \\
\hline $\begin{array}{l}\text { Rights and obligations related } \\
\text { to warranty agreements }\end{array}$ & $\begin{array}{l}\text { Financial assets and liabilities } \\
\text { recognized under lease agreements }\end{array}$ \\
\hline $\begin{array}{l}\text { Host financial instruments that } \\
\text { are separated from embedded } \\
\text { derivative instruments }\end{array}$ & $\begin{array}{l}\text { Financial instruments that are } \\
\text { classified as equity }\end{array}$ \\
\hline $\begin{array}{l}\text { Firm commitments involving } \\
\text { financial instruments }\end{array}$ & $\begin{array}{l}\text { Deposit liabilities of financial } \\
\text { institutions }\end{array}$ \\
\hline Written loan commitments & \\
\hline
\end{tabular}

Source: SFAS 159 (FASB, 2007)

Once again, FASB raises the requirements regarding the supply of information when fair value option is chosen, in such way that the investors, analysts and other users of financial statements have the possibility to fully understand in which degree is used this option, as well as a modality in which the occurred changes in fair value are reflected within the financial statements. The probability is big that the entities to 
choose the fair value option for all the components from a group of similar elements, but since SFAS 159 offers the possibility of individual selection, FASB solicits the presentation of some extra information where the option is applicable only upon some of the eligible elements within such a group. In this way, the entities are required to include, within the information regarding the fair value option, a description of those elements that are similar to those upon which the option was implemented, together with the partial option motivation. Additional, the entities are encouraged, but not imposed, that near the solicited information presented through SFAS 159, to keep in mind the solicitations regarding fair value within other standards, the perfect combination being considered the one in association with SFAS 157 and SFAS 107. All these are conceived with the aim to facilitate the debugging of managers' reasoning in implementation of the fair value. It is also necessary the presentation of ways in which the occurred changes in fair value of the financial instruments affect the result of the financial exercise, underlining the differences between the fair values and the contractual cash flows of certain elements.

One of the main problems that made its presence visible since the first applications of the standard, is related to the modality in which the reporting entities choose the fair value option in the case of financial assets available for sale (AFS) and of the investments held to maturity (HTM) that here introduced in accounting conformingly to SFAS 115. According to SFAS 115, the value carrying securities held for transactions were already introduced in accounting marked to market, the profits and losses being included in current earnings. The financial assets available for sale on the other side, are evaluated at a value given on the market at the date of each finalization of the financial situations, but the earnings and the losses generated by these value carrying securities avoid the income statement, being reported within the equity under the form of other adjustment elements, adjustment to other comprehensive income. The investments held to maturity are not introduced in accounting at their value given on the market; more rapidly, if there is not depreciation besides the temporary one in the value of these value-carrying securities, these are reflected within the financial statements at a depreciated cost. Many entities have well considered the risks and advantages of irrevocable utilization of the fair value option in order to reclassify the value carrying securities from the category of those available for sale and held to maturity that were introduces into accounting according to SFAS 115. 
Through such a decision, the entities could choose the fair value option for diminishing the investment value in certain value carrying securities, transferring them from the available for sale and held to maturity category in the one of those held for transactions, reporting in this way unrealized losses as a integrating part of the adjustments afferent to the cumulative effect foreseen by the new standard. Since these adjustments afferent to the cumulative effect are directly transferable within the retained earnings, any losses afferent to this value carrying securities would not be reflected within the income statement, even if the titles were afterwards sold. After this first application of SFAS 159, the changes in fair value appeared afterwards being reported within the present result.

During a conference organized for public institution auditors in April 2007, the leading members of SEC emitted an advertisement regarding the offer of this new standard of the possibility of creation some structural transactions with the goal of attaining a certain accounting result.

The evidences resulted as a following of the research activity made by Jack Ciesielski, the owner of a research company in the domain of investments - R.G. Associates Inc., shows that 60 entities have adopted SFAS 159 in the first trimester of 2007 under the permissively of early adopting. Other 12 entities have adopted the standard, but partly or totally changed their decision afterwards.

Seacoast Banking Corp. from Florida was one of the many entities that reconsidered this decision. Under the transitory conditions of SFAS 159, Seacoast opted to report at a fair value, starting with $1^{\text {st }}$ of January 2007 , value carrying titles of approximately 251 million dollars. The effect of adopting fair value was reflected under the form of some adjustments afferent to the cumulative effect within the retained earnings of the opening balance, and the changes appeared in the value of the securities after this data as a component of the current result, affecting the income statement. The adjustments afferent to the cumulative effect have diminished the reported result within the opening balance with 3.7 million dollars. Dennis S. Hudson, executive director of Seacoast, declares that at that respective time (within a press release from $25^{\text {th }}$ April which presented the performances of the entity for the first trimester), that the possibility to align in a correct way the financial results of these instruments with their economic value, permitting in this way the manifestation of an active management over the balance". The change in attitude appeared in may, when the entity announced that "the extra interpretations of SFAS 159 requirements in the case of an early adoption including the general comments recently brought by SEC, and the following analyses made by the accounting community, determined the change of option, concluding that all the value of adjustment afferent to the transaction should be reflected within the result of the first trimester of 2007 and not of the reported result afferent to the opening 
balance sheet." This revise is expected to diminish the result according to the applicability of GAAP's afferent to the first trimester with appreciatively 3.7 million dollars, or in other words, to diminish the result per share with 0.20 dollars (Ratcliffe, 2007, p. 61).

The analysts in the financial domain have foreseen than that in times in which the introduction in accounting of financial instruments at a fair value permits the manipulation of the obtained results by the entities that will belong to the past the moment the regulation organisms and investors were alerted. The suspicions were maintained still high in the case of fair values determined by the utilization of unobservable entry data, and implicitly leave place to some doubtable reasoning.

We consider that this standard surely makes extremely difficult the task of financial auditors put in the situation of appreciating in which degree the choice of the fair value option is justified. What remains for them to do, is to verify if SFAS 159 is implemented in a manner according to the basic objectives of the standard, reflecting the prevalence of economic over juridical. This assumes keeping a certain degree of professional skepticism in evaluating the facts and circumstances related to the utilization of fair value, for appreciating if the choice made in the aim of reflecting the economic reality and of obtaining a certain accounting result (Ratcliffe, 2007).

The analysis made regarding the effect the fair value option had upon the commercial banks' balance sheets within 2007 (in the case of those who opted for the early applicability allowed by SFAS 159) shoe that this had a limited influence, as it is concluded from the following chart. Less than 150 banks chose the fair value option according to first trimester reports, with the decreasing tendency for the rest of the year. Even in their case, the applicability of the option was limited to certain elements, within the portfolio of offered loans, only $2 \%$ being reported at a fair value. Even more, the majority was represented by housing loans accorded for residential areas that were willing to be secured, all belonging to a few banks of significant dimensions. We can say that the effect was somewhat more pronounced in the case of value carrying securities portfolios, because of the transfer of financial assets disposable for selling and of investments held to maturity in the category of those kept for transactions, these registering a value increase of 70 billion dollars. In this case, $85 \%$ from the total were reported at a fair value, again the majority being concentrate in the hands of some major institutions.

We can state, after the analysis of the concept that the fair value as well as from the point of view of the emitted regulation by IASB as well as by FASB, that SFAS 159 realizes the convergence of principle with the option of the fair value within IAS 39, differences being maintained regarding the solicited information, exceptions from the applicability and 
eligibility criteria regarding to the applicability of fair value, while IAS 39 was amended in the purpose of introduction of such restrictions, as a following of the initial decision of E.U. to eliminate the fair value option at the adoption of IFRS in the case of the consolidates financial situations of the entities quoted on the capital market. FASB considered also this alternative of restrictions, but rejected, considering that this will reduce the utilization of the evaluation of the fair value of the financial instruments, would increase the degree of complexity of the financial reporting, and would affect the capacity of the entities to compensate the accounting disagreements through the aid of a flexible and easy to implement fair value option. Another significant difference between the two standards stays in the fact that SFAS 159 treats the fair value option as being an evaluation option, while IAS 32 considers it a classification option.

As a following, as an example, according to SFAS 159, a receivable can be evaluated at the depreciated cost, of at the fair value. In a contrary way, according to IAS 32, a receivable stops being considered a receivable if this is evaluated according to the fair value option.

Tab. 2: The Impact of the Fair Value Option (FVO) on Selected Items within American Commercial Banks in 2007

\begin{tabular}{|c|c|c|c|c|c|}
\hline \multirow{2}{*}{ Period } & \multirow{2}{*}{$\begin{array}{c}\text { Number of } \\
\text { Com. Banks } \\
\text { which have } \\
\text { chosen FVO }\end{array}$} & \multicolumn{2}{|c|}{$\begin{array}{l}\text { Loans and Leases } \\
\text { (in billions USD) }\end{array}$} & \multicolumn{2}{|c|}{$\begin{array}{l}\text { Trading Assets } \\
\text { (in billions USD) }\end{array}$} \\
\hline & & $\begin{array}{c}\text { Reported } \\
\text { under FVO }\end{array}$ & Total & $\begin{array}{c}\text { Reported } \\
\text { under FVO }\end{array}$ & Total \\
\hline Q1/2007 & 148 & 83 & 5.910 & 563 & 679 \\
\hline Q2/2007 & 122 & 102 & 6.100 & 614 & 723 \\
\hline Q3/2007 & 111 & 107 & 6.316 & 678 & 803 \\
\hline Q4/2007 & 107 & 120 & 6.561 & 737 & 867 \\
\hline
\end{tabular}

Source: Consolidated Reports of Condition and Income (Call Report) (FFIEC, 2008)

\section{Conclusion: Fair Value - Ally or Enemy?}

The use of fair value it's a subject long debated, during last 12 months, big financial institutions recognizing, financial statements' frame, loss of more than 150 billion USD, mostly under the utilization of market values (Beeler et al., 2009).In the same time, SEC investigate now the possibility 
of use, from some entities under research, of different market value for the same securities. From this perspective, nobody can deny the fact that the use of the values on the market involves some problems, especially in extremely difficult periods from the market's point of view. For all that, the defenders of fair value bring the argument, the capacity to ensure a certain connection to the reality, associated with another aspect of reality, namely own shortcomings of alternatives for the market value. We refer here to $t$ the fact that, neither the reflection value of some elements only in their costs, under the historical cost principle, would not provide to the investors a better image concerning the problems with confront now the financial institutions.

The effects of SFAS 157 implementation are presented today, a series of financial institutions trained in loans guarantee systems declare that they have been affected in a significant way by the accounting standards implementation regarding the fair value. In the light of the recent problems caused by the sub-prime credits crisis, SEC intents to emit, sonly, advices that would permit the entities to consider a wider series of values when they evaluate the assets and debts through reference to the market. In the same time, FASB does not plan any revising of the existent rules, continuing to consider as necessary that the entities should evaluate the assets and debts and even then, when the result is a significant diminution. Michael R. Young ${ }^{2}$, member of the Financial Accounting Standards Advisory Council (FASAC) of FASB, actively participating within the process of implementation of SFAS 157, declares on 7th of March 2008:

For those inclined to blame accounting, the real culprit in the sub-prime mass is a fairly new standard ...SFAS 157. (Quoted by Beeler, Evans, Turner, 2009)

The multitude of American accounting regulation that referred to fair value, the majority in the domain of financial instruments, often the intersection of their forecasts, but also the adjustments gradually imposed by the evolution of the financial domain, potentate by increasing the level of acceptance of fair value like evaluation of attribute, noted the need of developing of a standard with wide applicability, a kind of a sole source to ensure procedural advice of high level in order to offer consistent estimates.

2 Lawyer, having the role of adviser of the American Institute of Certified Public Accountants, being named by the Accounting today magazine, "one of the most influential 100 people in accounting". 
Previous to the issuance of SFAS 157, a series of fair value definitions and limited recommendations regarding its applicability were spread within more pronouncements emitted by FASB, the existing differences generating in this way inconsistencies of the American accounting referential, without discussing about the effect that these had over the complexity of the applicability of US GAAP's. FASB reacted in this direction, elaborating SFAS 157 with the goal to increase the degree of consistency and comparability in the domain of fair value evaluation, as well as for determining the offer of further information regarding the realization of this process, value reflected without value only if it was accompanied of other joint information. This new standard plays the role of a conceptual frame of fair value evaluation in the American accounting referential frame, determining changes in the accounting practices of some of the entities, without imposing new evaluation of fair value, but only through requirements applicable to situations that impose or permit this thing through other accounting requirements emitted by the Board.

SFAS 157 brings additional rigor concerning the estimation of fair values, especially through its central component of describing the fair value hierarchy, presenting the three levels of the entry data afferent to the evaluation pattern that can be used. Every level reduces the credibility and relevance degree of estimated values, but it is the reality consequence in what concerns the reduced possibility of use of the superior levels. Excepting the transacted value securities, generally, the identification of some assets and debts identically transacted between active markets is not possible. In these situations, the standard allows observed assets to be adjusted in such a manner that it allows the quantification of the differences between the evaluated elements and those similar elements with a determinable evaluation. These differences may reflect different conditions, locations as well as other constraints concerning the vendibility of the evaluated elements (Miller and Bahnson, 2007). Of course, in parallel with the acceptance of a series of adjustments through these levels, in which there use must be considered in a successive manner, starting from the first level, the choice of one of the three depending on the existing conditions at the evaluation time, FASB makes effort in not losing control over the effect of this flexibility. We are referring here of the many solicited details to be presented, so that the users of the information supplied by these evaluations have the possibility of knowing the way in which the estimate fair value was realized. However, the contribution of SFAS 157 is not questionable in transferring 
a series of accounting standards to the 21 st century by increasing the fair value estimation rigor.

SFAS 159 is the one who comes to exploit the launching ramp built with the help of its predecessor, introducing the option of fair value to assets and financial debts, which can be selected individually by the reporting entity, soliciting on the other hand of an additional series of information, so it can allow the users comparisons between financial situations that use different evaluation basis. The merit of this standard is to encourage the use of fair value in evaluating financial instruments, through a relative simple method of application of the fair value option, yet the amendments brought in 2005 as a consequence of pressures coming from E.U. relations, it restricts the option of fair value. On the other hand, IAS 39 is elaborated in such a manner that the option of fair value comes from the definition of different types of assets and financial debts, more likely as an evaluation principal, this way becoming extremely complex if not inscrutable most of the times (Cairns, 2005). At once with the flexibility of the standard, they also rise the difficulty of developing a professional reasoning of the audits in evaluating the facts and the circumstances of using the fair value, to appreciate is the choice is made to reflect the economic reality or for obtaining a certain accounting result (Ratcliffe, 2007).

The opinion of many specialists in the area support the development of the two reference standards in the line of fair value, predicting on a long term, a decrease of the importance of traditional financial reporting based in historic cost in parallel with the gaining of this terrain by the financial reporting based in fair values. In fact we can say that this process of turning down the values has already been initiated, in a way or another, decades ago, not representing a surprise in our days, SFAS 157 and 159 being introduced in this tendency manifested along time (Miller and Bahnson, 2007).

What this analysis of regulations issued by FASB teaches us is that fair values have been inserted into American standards gradually, over many decades, through a large number of standards such as those regarding stocks, investments, financial instruments of different types and enterprise combining. As such, we cannot look at fair value accounting as being a theoretical and abstract thing that can be put into action at an indefinite time, requiring correlations and grasps in the implementation context. 
Even since the late ' 80 s, FASB has had a single goal that meant reflecting all financial instruments, along many other assets and debts, at the time of balance, at their fair value, fair value accounting being an important element in FASB's agenda on a long term. Actually, we could look at SFAS 33*, which required extra information about current costs and permanent estimates regarding corporate non-financial assets, issued in 1979, as being a fist attempt at fair value accounting. At present, more than 40 standards from US GAAP's, require (or allow) entities fair value asset and debt evaluation. The majority is focused around problems regarding financial instruments (such as SFAS 105*, SFAS 107, SFAS 114, SFAS 115, SFAS 118, SFAS 119*, SFAS 125*, SFAS 133, SFAS 138, SFAS 159), others having a general characteristic (SFAS 157) or targeting other distinctive aspects, like SFAS 142 that deals with goodwill.

The following table 3 shows a parallel of the main standards regarding ${ }^{3}$ fair value, developed on time ${ }^{4}$ by the two major accounting regulatory setting bodies, IASB and FASB.

Objectives like the offer of financial information to reflect clarity, transparency and the easiness to make comparisons are formulated often by diverse parts implied in the complex market of accounting information. In order for these to be realized, it is necessary that all these parts to come to a same conclusion, in theory as well as in practice, because they represent in fact the wished result (Wolosky, 2007). Fair value has, as We have shown in a detailed manner, its supporters, but also its' inquisitors, motivated by its advantages and limits, while an orientation in future of the regulations upon historical values does not represent itself an optimistic vision upon the future. A series of regulatory organisms, comities and commissions, studies, some in collaboration, others individually, ways to improve these aspects that regard accounting and audit, but only future will show us the direction things will evolve, how well they have collaborated and the impact that they want to have upon the market, the way remaining opened to multiple analysis and researches in the domain.

3 Defining, allowing the utilization, soliciting the utilization or making other references to the fair value.

4 Each standard is positioned at the date of the first apparition, without mentioning the following amendments, and the abrogated standards are correspondingly marked. 
Bonaci, C. G. - Strouhal, J. - Matis, D.: Fair Value Accounting and Measurement through FASB's Developments.

Tab. 3: IASB and FASB Standards Dealing with Fair Value ${ }^{5}$

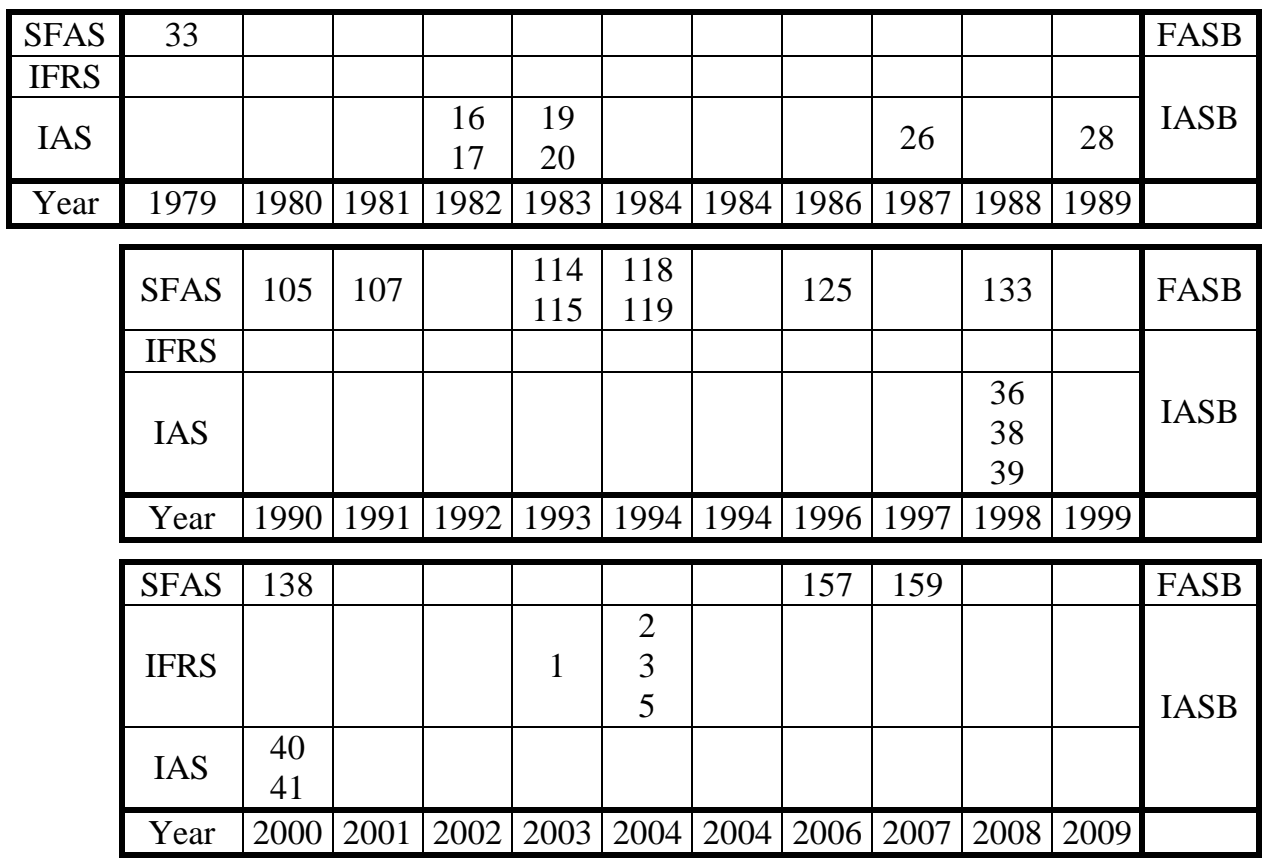

Source: FASB (2009), IASB (2007) + own analysis

5 SFAS 33 Financial Reporting and Changing Prices*, SFAS 105 Disclosure of Information about Financial Instruments with Off-Balance-Sheet Risk and Financial Instruments with Concentrations of Credit Risk ${ }^{*}$, SFAS 107 Disclosures about Fair Value of Financial Instruments, SFAS 114 Accounting by Creditors for Impairment of a Loan-an amendment of FASB Statements No. 5 and 15, SFAS 115 Accounting for Certain Investments in Debt and Equity Securities, SFAS 118 Accounting by Creditors for Impairment of a Loan-Income Recognition and Disclosures - an amendment of FASB Statement No. 114, SFAS 119 Disclosure about Derivative Financial Instruments and Fair Value of Financial Instruments*, SFAS 125 Accounting for Transfers and Servicing of Financial Assets and Extinguishments of Liabilities*, SFAS 133 Accounting for Derivative Instruments and Hedging Activities, SFAS 138 Accounting for Certain Derivative Instruments and Certain Hedging Activities-an amendment of FASB Statement No. 133, SFAS 142 Goodwill and Other Intangible Assets, SFAS 157 Fair Value Measurements, SFAS 159 The Fair Value Option for Financial Assets and Financial Liabilities-Including an amendment of FASB Statement No. 115. IAS 16 Property, Plant and Equipment, IAS 17 Leases, IAS 19 Employee Benefits, IAS 20 Accounting for Government Grants and Disclosure of Government Assistance, IAS 26 Accounting and Reporting by Retirement Benefit Plans, IAS 28 Investments in Associates, IAS 36 Impairment of Assets, IAS 39 Financial Instruments: Recognition and Measurement, IAS 40 Investment Property, IAS 41 Agriculture, IFRS 1 First-time Adoption of International Financial Reporting Standards, IFRS 2 Share-based Payment, IFRS 3 Business Combinations, IFRS 5 Non-current Assets Held for Sale and Discontinued Operations. 


\section{References}

[1] Barth, M. E. (1991): Relative Measurement Errors among Alternative Pension Asset and Liability Measures. Accounting Review, 1991, vol. 66, no. 3, pp. 433-463.

[2] Barth, M. E. - Landsman, W. R. (1995): Fundamental Issues Related to Using Fair Value Accounting for Financial Reporting. Accounting Horizons, 1995, vol. 9, no. 4, pp. 97-107.

[3] Beeler, J. - Evans, A. - Turner, K. (2009): How Fair is Fair Value. [on-line], San Diego, Proceedings of American Society of Business and Behavioral Sciences, 2009, vol. 16, no.1, 5 pp. [cit. $12^{\text {th }}$ November, 2009], <http://asbbs.org/files/2009/PDF/B/BeelerJ.pdf>.

[4] Botosan, C. A. - Beatty, A. L. - Hopkins, P. E. - Nelson, K. K. Venkatachalam, M. (2005): Response to the FASB's Exposure Draft on Fair Value Measurements. Accounting Horizons, 2005, vol. 19, no. 3, pp. 187-196.

[5] Cairns, D. (2005): International Briefing Financial Reporting. Accountancy, 2005, vol. 130, no. 1308, p. 85-86.

[6] FASB (2007): Statement of Financial Accounting Standards 157 Fair Value Measurements. Norwalk, Financial Accounting Standards Board, 2007.

[7] FASB (2009): Statement of Financial Accounting Standards. Norwalk, Financial Accounting Standards Board, 2007.

[8] FFIEC (2008): Consolidated Reports of Condition and Income (Call Report). Arlington, Federal Financial Institutions Examination Council, 2008.

[9] Fishman, J. E. - Pratt, S. P. - Morisson, W. J. (2007): Standards of Value Theory and Applications. New York, Wiley, 2007.

[10] IASB (2007): International Financial Reporting Standards (IFRSs). London, International Accounting Standards Board, 2007.

[11] Landsman, W. (1986): An Empirical Investigation of Pension Fund Property Rights. The Accounting Review, 1986, vol. 61, no. 4, pp. 662-691.

[12] Miller, P. B. W. - Bahnson, P. R. (2007): Refining Fair Value Measurement. FASB 157 Upgrades the Quality of Financial Reporting. Journal of Accountancy, 2007, vol. 103, no. 11, pp. 30-36. 
Bonaci, C. G. - Strouhal, J. - Matis, D.: Fair Value Accounting and Measurement through FASB's Developments.

[13] Ratcliffe, T. A. (2007): The Finer Points of Fair Value FASB 159 opens up options. Journal of Accountancy, 2007, vol. 103, no. 12, pp. 30-36.

[14] Ronnen, J. (2008): To Fair Value or Not to Fair Value: A Broader Perspective. Abacus, 2008, vol. 44, no. 2, pp. 181-208.

[15] Wolosky, H. (2007): Clarity, Transparency, and Ease of Comparability. Practical Accountant, 2007, vol. 40, no. 6, p. 6. 


\title{
Fair Value Accounting and Measurement through FASB's Developments
}

\author{
Carmen Giorgiana BONACI - Jiři STROUHAL-Dumitru MATIS
}

\begin{abstract}
Our research follows the path of fair value as a term and concept, as well as its disclosure, measurement and recognition back from 1953 until our days, and analyzes the regulations issued by United States Accounting Standard setters, through the point of view of the historical events, which led to their appearance. Our study brings its' contribution to complementing growing literature on the value relevance of fair value, but focuses on the assessment of fair value as a financial reporting standard for financial instruments. The objective of the paper is to link the regulations with the historical events, which have guided them to their current shape and meaning. In doing so, we identified several key issues, which need to be analyzed, and through which we draw our conclusions after a closer analysis of SFAS's foresights. In financial reporting, United States and International Accounting Standard setters have issued several disclosures, measurement and recognition standards for financial instruments. We conclude our study noticing how all indications are that both standard setters mandate recognition of financial instruments at fair value, despite all fingers currently being pointed toward fair value as a "scape goat" for the recent events. The relevance of the study is emphasized when looking through the lens of the current financial crisis, derivative financial instruments being a central element. With Churchill's words and believe in our thoughts, "the deeper we can look into the past, the farther we'll see into the future" we plead for fair value assessment by underlying its advantages, while being aware of its limitations.
\end{abstract}

Key words: Fair Value; Hierarchy Level; Reliability; Relevance; Estimates; Financial Crisis.

JEL classification: M41. 